\title{
Australian Journal of \\ Spatial arrangement of maize plants aiming to maximize grain yield in the hybrid BRS-3046
}

\author{
Marcus Willame Lopes Carvalho ${ }^{1}$, Edson Alves Bastos ${ }^{2}$, Milton José Cardoso ${ }^{2}$, Aderson Soares de Andrade \\ Junior' ${ }^{2}$, Carlos Antônio Ferreira de Sousa ${ }^{2}$
}

'Center of Agrarian Sciences, Federal University of Piaui - UFPI, marcuswillame@hotmail.com, 999978911, Teresina, PI, Brazil

${ }^{2}$ Embrapa Mid-North, 3198-0500, Teresina, PI, Brazil

*Corresponding author: edson.bastos@embrapa.br

\begin{abstract}
The objectives of this study were to: (i) evaluate the effect of different spatial arrangements on morpho-physiological characteristics and (ii) determine the optimal spatial arrangement to maximize grain yield of the maize hybrid BRS-3046 grown in

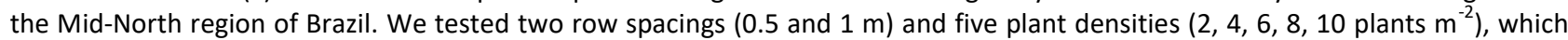
corresponded to 10 different plant spatial arrangements. Different morphophysiological variables, gas exchange rates and grain yield were measured. The increased planting density led to a linear increase in LAl, regardless of row spacing, while the net $\mathrm{CO}_{2}$ assimilation rate increased until the density of 4 and 6 plants $\mathrm{m}^{-2}$, under a row spacing of 0.5 and $1.0 \mathrm{~m}$, respectively. On the other hand, we found a linear reduction in the stomatal conductance with increasing planting density. The intercellular $\mathrm{CO}_{2}$ concentration and the transpiration rate were higher in the widest row spacing. The instantaneous efficiency of carboxylation, in turn, showed a slight increase up to the density of six plants $\mathrm{m}^{-2}$, then falling, regardless of row spacing. Increasing plant density resulted in a linear increase in plant height and ear insertion height, regardless of row spacing. However, it had an opposite effect on stem diameter. Grain yield, in turn, increased up to 7.3 plants $\mathrm{m}^{-2}$ at a row spacing of $0.5 \mathrm{~m}$ and 8 plants $\mathrm{m}^{-2}$ at a row spacing of $1.0 \mathrm{~m}$. This spatial arrangement was considered as ideal for achieving maximum yield.
\end{abstract}

Keywords: Zea mays; plant density; spacing between rows; leaf gas exchange; physiology.

\section{Introduction}

The concept of modern agriculture presupposes the intensive and rational use of inputs by agricultural systems aiming to achieve the maximum potential productivity. The advances achieved in recent years have been able to meet the current demand for agricultural products, even in a scenario of extreme competitiveness, legal restrictions to open new agricultural frontiers and scarcity of natural resources. In addition, there are still the emergences of extreme weather events and increased production costs, which cannot be neglected. Thus, small differences in a crop yield can have great economic significance, especially when the prodution scale is taken into consideration. The maize crop fits in this situation because it is a commodity, which is grown worldwide, especially for human and animal food. In Brazil, maize production reached 82.92 million tons in the 2017/2018 crop season, in a cultivated area of 16.69 million hectares, which resulted in an average grain yield of $4.96 \mathrm{Mg}$ $\mathrm{ha}^{-1}$ (CONAB, 2018).

In addition to soil liming and fertilization, water availability, adequate pest and disease control, reaching high crop yields depends on planting density and plant spatial arrangement. The ideal plant spatial arrangement is that which provides the best plant distribution in an area, minimizing the intraspecific competition for water, light and nutrients (Santos et al., 2018). Changes in plant spatial arrangement can affect plant architecture, growth and development patterns, radiation interception by the canopy, influencing photosynthesis rates, carbohydrate production and, consequently, yield (Abuzar et al., 2011; Lima et al., 2012). The maize leaves in the middle third of the canopy contribute most with photoassimilates for higher yields (Zhao, 1981). However, under high planting densities, the intensity of light reaching the leaves in that canopy portion is lower and $\mathrm{CO}_{2}$ concentration decreases, which reduces the photosynthetic activity and accelerates leaf senescence (Wang et al., 2017). In addition, other vegetative organs may become overdeveloped as plant competition increases, which may drain energy and nutrients that would otherwise be directed to grain yield (Gondal et al., 2017). Souza et al. (2013) observed that increasing plant density above the ideal stimulates apical dominance, induces pollen sterility, and decreases the number of ears per plant and the number of grains per ear.

The grain yield can be increased by maximizing the photosynthetic efficiency, which can be obtained by improving the interception of photosynthetically active radiation by the canopy (Marchão et al., 2006), from the use of the most suitable spatial arrangement for the crop. Several studies have evaluated the use of maize cultivars at different row spacings and plant populations (Santos et al., 
2018, Shi et al., 2016, Buso et al. 2016, Xue et al., 2016), since modern hybrids tolerate higher planting densities, reaching higher yields (Kappes et al., 2011; Testa 2016). It is therefore appropriate to determine the most suitable spatial arrangement for these emerging new varieties and commercial hybrids, depending on the prevailing growing conditions. Among the new maize genotypes released by Embrapa, which do not yet have the ideal plant density to achieve maximum yield, is the triple hybrid BRS-3046. Thus, the objectives of this study were to: (i) evaluate the effect of different spatial arrangements on morpho-physiological characteristics and (ii) determine the optimal spatial arrangement to maximize grain yield of the maize hybrid BRS-3046 grown in the Mid-North region of Brazil.

\section{Results}

\section{Effect of row spacing and planting density on leaf area index and gas exchange rates}

Based on statistical analysis, there was an interaction between row spacing and planting density only for net $\mathrm{CO}_{2}$ assimilation rate. Stomatal conductance was affected by both row spacing and planting density, whiles the intercellular $\mathrm{CO}_{2}$ concentration and the transpiration rate were affected by row spacing. The leaf area index and the instantaneous efficiency of carboxylation were affected only by planting density. The instantaneous water use efficiency was not influenced by any of the treatments or their interaction (Table 1).

The increase in planting density resulted in a linear increase in LAl, regardless of row spacing (Fig 1A). On the other hand, there was a linear reduction in stomatal conductance at both row spacings (Fig 1B), although it remained higher at the $1.0 \mathrm{~m}$ row spacing ( $\mathrm{Fig} 1 \mathrm{C}$ ). The intercellular $\mathrm{CO}_{2}$ concentration (Fig 1D) and the transpiration rate (Fig 1E) were higher the higher row spacing. The instantaneous efficiency of carboxylation, in turn, showed a slight increase at the row density of 6 plants $\mathrm{m}^{-2}$, with subsequent decrease, regardless of the row spacing (Fig 1F).

Based on statistical response surface study, it was found that the increase in row spacing and planting density also increased the net $\mathrm{CO}_{2}$ assimilation rate (Fig 2). The combination of the $1.0 \mathrm{~m}$ row spacing and planting density of six plants $\mathrm{m}^{-2}$ provided the maximum net $\mathrm{CO}_{2}$ assimilation rate, around of $43.85 \mu \mathrm{mol} \mathrm{CO} \mathrm{m} \mathrm{m}^{-2} \mathrm{~s}^{-1}$.

At the distance of $0.5 \mathrm{~m}$ between the rows and in a density of 10 plants $\mathrm{m}^{-2}$, LAI increased up to $71 \mathrm{DAE}$, whereas in the 2 plants $\mathrm{m}^{-2}$ it increased up to 81 DAE (Fig 3). Under $1.0 \mathrm{~m}$ row spacing and planting density of 10 plants $\mathrm{m}^{-2}$ LAl increased up to $71 \mathrm{DAE}$, whereas in the planting density of 2 plants $\mathrm{m}^{-2}$ it increased up to 76 DAE (Fig 4).

Effect of row spacing and plant density on the morphophysiological varibles and grain yield

It was found a significant interaction between row spacings and plant densities for stem diameter and grain yield. Plant height and ear insertion height were affected only by planting density (Table 2).

Increasing plant density resulted in a linear increase in plant height and ear insertion height (Fig 5A and 5B), regardless of row spacing. An opposite effect was found on stem diameter as shown in the response surface curves (Fig 6A).

According to the adjustment of the quadratic polynomial response surface, the increase in row spacing and planting density increased grain yield. A maximum of $7.83 \mathrm{Mg} \cdot \mathrm{ha}^{-1}$ was obtained with the combination of $0.5 \mathrm{~m}$ row spacing and a planting density of eight plants $\mathrm{m}^{-2}$ (Fig 6B).

\section{Discussion}

The rise in LAl as a function of increasing plant density is a commonly result in the literature and has already been described in maize plants by several authors (Valadabadi et al., 2010; Abuzar et al., 2011; Gou et al., 2017; Ren et al., 2017). According to Gonzales et al. (2018), although the increase in plant density reduces plant individual leaf areas, the increase in LAI occurs due a higher number of plants per area. However, when observed along the growth season, the reduction of planting density increased the time required for maize plants to reach maximum LAI. Therefore, at low densities LAI takes longer to reach its maximum and shows a later leaf senescence. According to Antoniettaa et al. (2014), higher plant density accelerates leaf senescence by reducing the photosynthesis rate and consequently the nutrient availability for grain yield.

The leaf area is important for the interception of light radiation (Ricaurte et al., 2016), but its increase is desirable only to the limit where the photosynthetic activity is not impaired by self-shading (Argenta et al., 2001). According to Pimentel (1998) the lower leaves shaded by the upper leaves end up receiving less light and, due to the lower photosynthetic capacity, may even become a sink instead of source of assimilates. In this study, the ideal density of maize plants for the net $\mathrm{CO}_{2}$ assimilation rate and the instantaneous carboxylation efficiency is concerned to the LAI where their values were higher. From that point, both variables showed a downward trend, although the instantaneous carboxylation efficiency curve was much smoother. The fact that the net $\mathrm{CO}_{2}$ assimilation and stomatal conductance rates were higher with the increase in row spacing could be related to a higher interception of light between rows, mainly with wider spacing. Wang et al. (2017) evaluated the effect of shading on maize plants and observed a significant reduction in the net photosynthetic rate.

The trend towards alteration of LAI as a function of plant density (Fig $1 \mathrm{~A}$ ) was inversely related to stomatal conductance rate (Fig 2B). This result suggests a close relationship with self-shading, which causes a marked decrease in stomatal density and consequently in stomatal conductance (Cabrera-Bosquet et al., 2017). Barradas et al. (2018) verified that maize plants under low luminosity presented less stomatal conductance when compared to plants under high light intensity. Probably the highest intercellular $\mathrm{CO}_{2}$ concentration (Fig 1D) and the highest transpiration rates (Fig $1 \mathrm{E}$ ) observed in plants row spaced at $1.0 \mathrm{~m}$ compared to those at $0.5 \mathrm{~m}$ were due to higher stomatal conductance rates observed at the wider row spacing (Fig 1C). In general, leaves that receive more light require higher amounts of $\mathrm{CO}_{2}$, which only a higher amount of stomata per area is able to provide. On the other hand, the shaded leaves do not need as many stomata because they do not have light to provide the photons that will boost 
Table 1. Summary of variance analysis for the effects of row spacings and planting densities on leaf area index, gas exchange rates and derived parameters in maize triple hybrid plants BRS-3046 grown under drought conditions in Teresina, $\mathrm{PI}, \mathrm{Brazil}$.

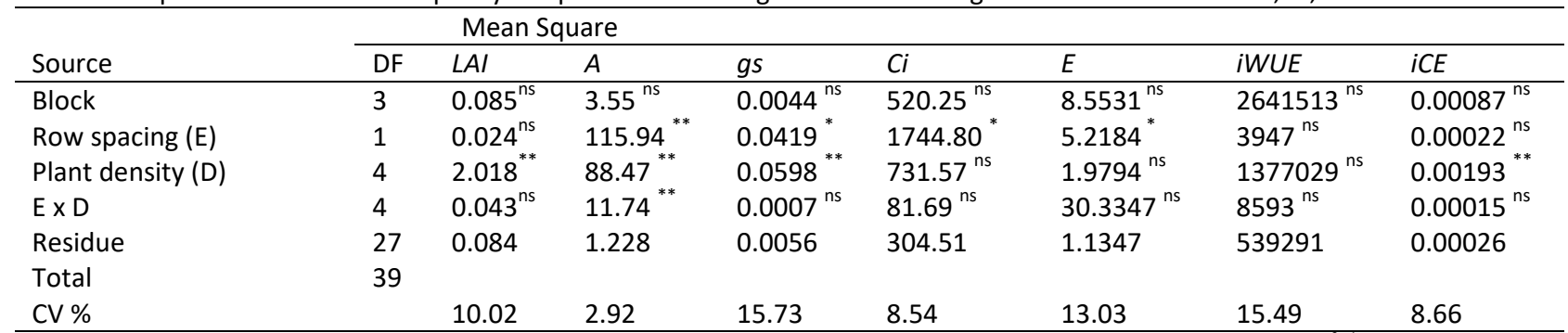

${ }_{n s, * * *}$ - Not significant, and significant at $5 \%$ and $1 \%$ of probability, respectively, according to $\mathrm{F}$ test. Leaf area index $\left(\mathrm{LAl}^{2}\right)$, net $\mathrm{CO}_{2}$ assimilation rate $\left(\mathrm{A}, \mu \mathrm{mol} \mathrm{CO}^{-2} \mathrm{~m}^{-2} \mathrm{~s}^{-1}\right)$, stomatal conductance (gs, $\mathrm{mmol} \mathrm{H}_{2} \mathrm{O} \mathrm{m}^{-2} \mathrm{~s}^{-1}$ ), intercellular $\mathrm{CO}_{2}$ concentration $\left(\mathrm{Ci}, \mu \mathrm{mol} \mathrm{CO} \mathrm{s}^{-1}\right)$, transpiration rate $\left(\mathrm{E}, \mathrm{mmol} \mathrm{H}_{2} \mathrm{O} \mathrm{m}^{-2} \mathrm{~s}^{-1}\right)$, instantaneous water use efficiency (iWUE, $\left.\mu \mathrm{mol} \mathrm{CO}_{2} \mathrm{mmol}^{-1} \mathrm{H}_{2} \mathrm{O}\right)$ and instantaneous carboxylation efficiency (iCE, $\left.\mathrm{mol} \mathrm{m}^{-2} \mathrm{~s}^{-1}\right)$.

A

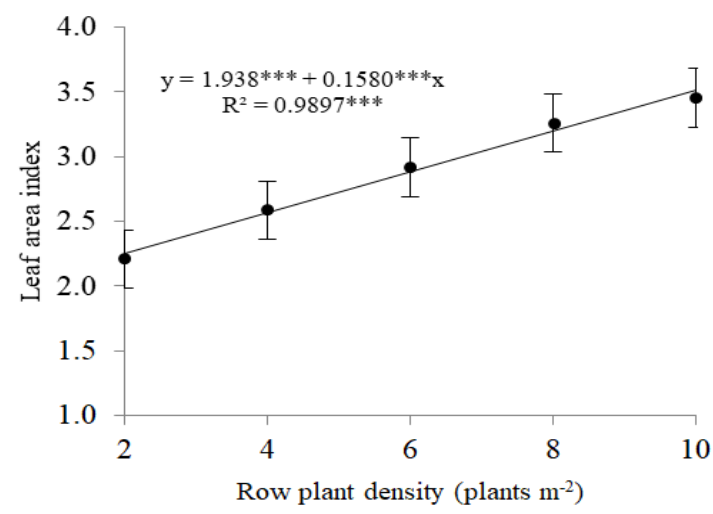

$\mathrm{C}$

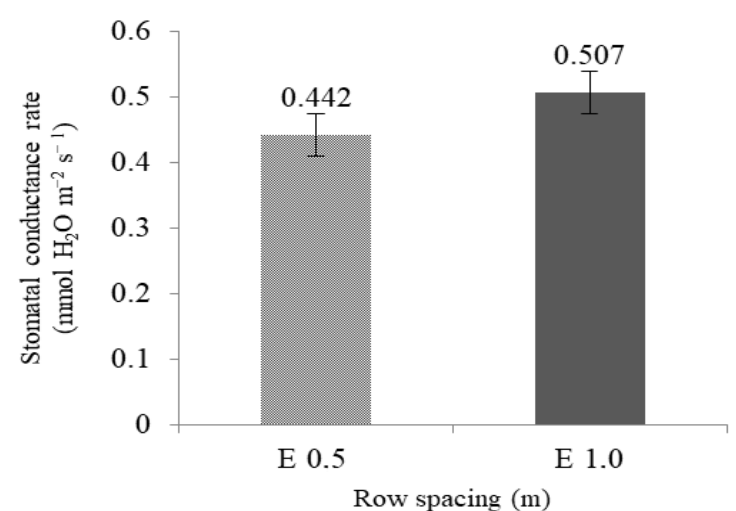

$\mathrm{E}$

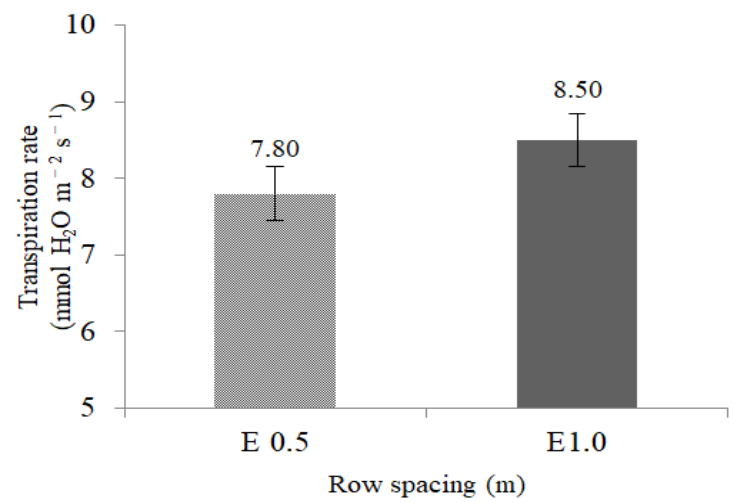

$\mathrm{B}$

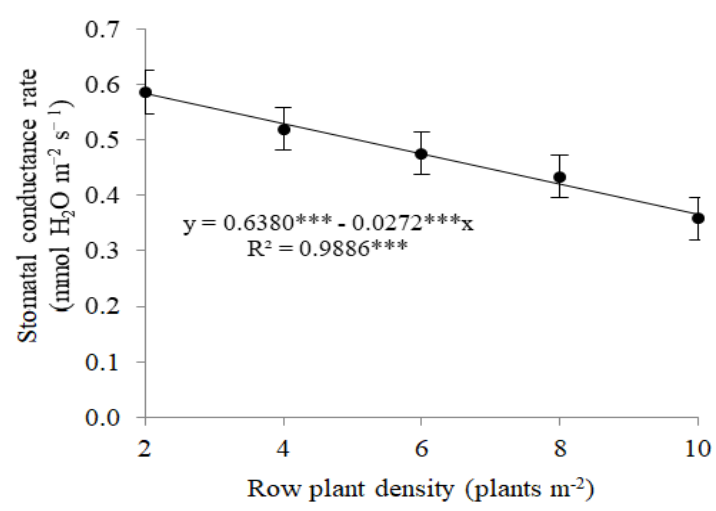

$\mathrm{D}$

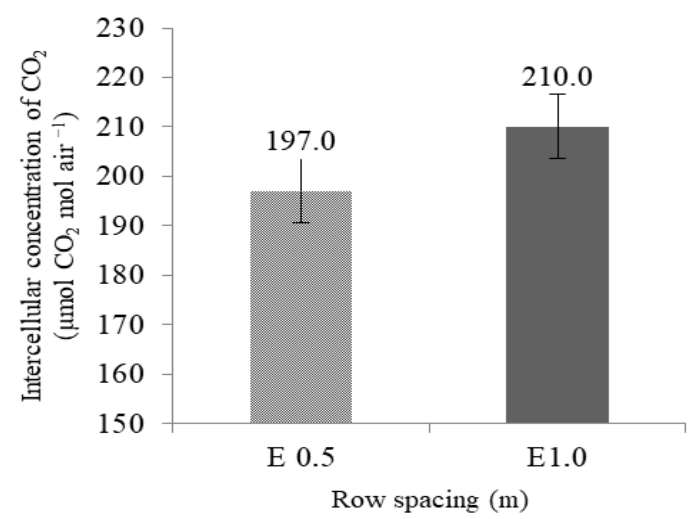

$\mathrm{F}$

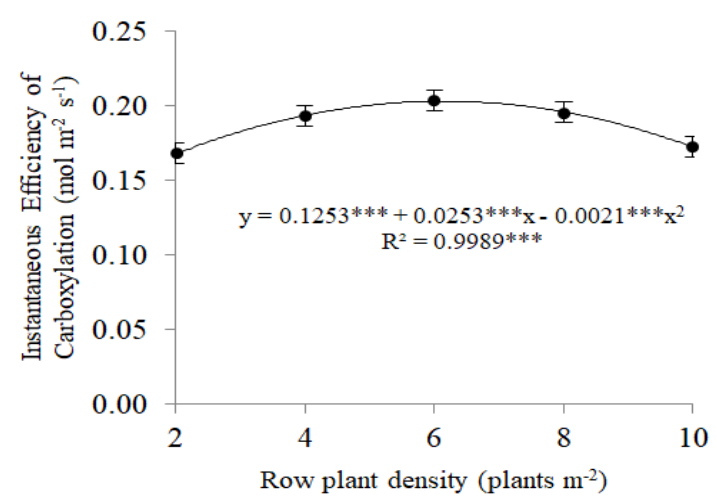

Fig 1. Effect of the row spacing and plant density on leaf area index and parameters derived from gas exchange on plant leaves of maize triple hybrid BRS-3046 cultivated under rainfed conditions in Teresina, PI, Brazil. Leaf area index (A), stomatal conductance - row plants density effect (B), intercellular concentration of $\mathrm{CO}_{2}(\mathrm{C})$, stomatal conductance - row spacing efect (D), transpiration rate (E) and instantaneous carboxylation efficiency (F). Significance according to $\mathrm{F}$ test: ${ }^{\prime * * * \prime} 0.001 \%^{(* * \prime} 0.01 \%^{\prime *}$ $0.05 \%$ ' $0.1 \%$ of probability. 
Table 2. Summary of variance analyzes of the effects of row spacing and planting densities on morphological characteristics and grain yield of the maize triple hybrid BRS-3046 under rainfed conditions in Teresina, PI, Brazil. Plant height $(P H, \mathrm{~cm})$, ear insertion height $(E I H, \mathrm{~cm})$, stem diameter $(S D, \mathrm{~mm})$ and grain yield $(G Y, M g$ $h a^{-1}$ )

\begin{tabular}{|c|c|c|c|c|c|}
\hline \multirow[b]{2}{*}{ Source } & \multicolumn{5}{|c|}{ Mean square } \\
\hline & DF & $\mathrm{PH}$ & EIH & SD & GY \\
\hline Block & 3 & $3.678^{n s}$ & $9.34^{\mathrm{ns}}$ & $0.843^{\mathrm{ns}}$ & $0.119^{\mathrm{ns}}$ \\
\hline Row spacing (E) & 1 & $30.625^{\mathrm{ns}}$ & $5.89^{\mathrm{ns}}$ & $1.414^{\mathrm{ns}}$ & $1.388^{*}$ \\
\hline Row plant density (D) & 4 & $268.857^{* *}$ & $504.56^{* *}$ & $81.398^{* *}$ & $13.205^{* *}$ \\
\hline$E \times D$ & 4 & $46.138^{\mathrm{ns}}$ & $9.77^{\mathrm{ns}}$ & $2.835^{*}$ & $0.315^{*}$ \\
\hline Residue & 27 & 26.440 & 12.08 & 0.0836 & 0.108 \\
\hline Total & 39 & & & & \\
\hline CV \% & 10.02 & 2.65 & 3.12 & 5.01 & 4.83 \\
\hline
\end{tabular}

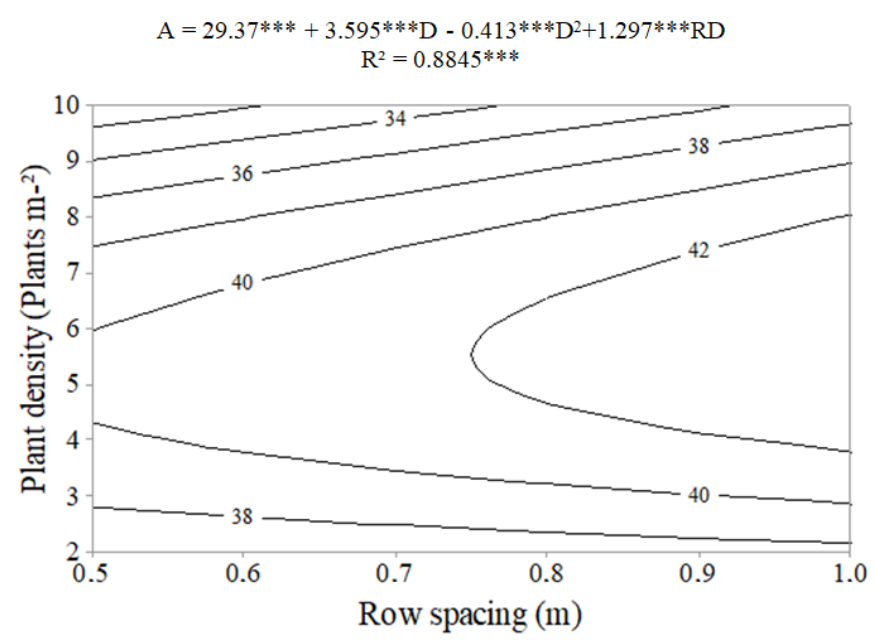

Fig 2. Response surface for net $\mathrm{CO}_{2}$ assimilation rate (A) according to row spacing and plant density in maize triple hybrid BRS-3046 plants cultivated under rainfed conditions in Teresina, PI, Brazil. Significance according to $\mathrm{F}$ test: (***) $0.001 \%{ }^{\prime * * \prime} 0.01 \%{ }^{\prime * \prime} 0.05 \%$ '' $0.1 \%$ of probability.

ns, **** - Not significant, and significant at $5 \%$ and $1 \%$ of probability, respectively, according to $\mathrm{F}$ test.

Table 3. Chemical composition of the soil from the experimental area.

\begin{tabular}{lllllllllllll} 
Depth & $\mathrm{OM}$ & $\mathrm{pH}$ & $\mathrm{P}$ & $\mathrm{K}^{+}$ & $\mathrm{Ca}^{2+}$ & $\mathrm{Mg}^{2+}$ & $\mathrm{Na}^{+}$ & $\mathrm{H}^{+}+\mathrm{Al}^{3+}$ & $\mathrm{SB}$ & $\mathrm{CEC}$ & $\mathrm{V}$ & $\mathrm{m}$ \\
\cline { 2 - 11 } \\
$(\mathrm{cm})$
\end{tabular}

Source: Soil Laboratory - Embrapa Mid-North. Soil Organic Matter $(\mathrm{MO})$, Hydrogen Potential $(\mathrm{pH})$, Phosphorus $(\mathrm{P})$, Potassium $\left(\mathrm{K}^{+}\right)$, Calcium $\left(\mathrm{Ca}^{2+}\right), \mathrm{Magnesium}\left(\mathrm{Mg}^{2+}\right)$, Sodium $\left(\mathrm{Na}^{+}\right)$, Hydrogen $\left(\mathrm{H}^{+}\right)$, Aluminum $\left(\mathrm{Al}^{3+}\right)$, Base sum, Cation exchange capacity (CEC), base saturation $(\mathrm{V})$, aluminum saturation $(\mathrm{m})$.
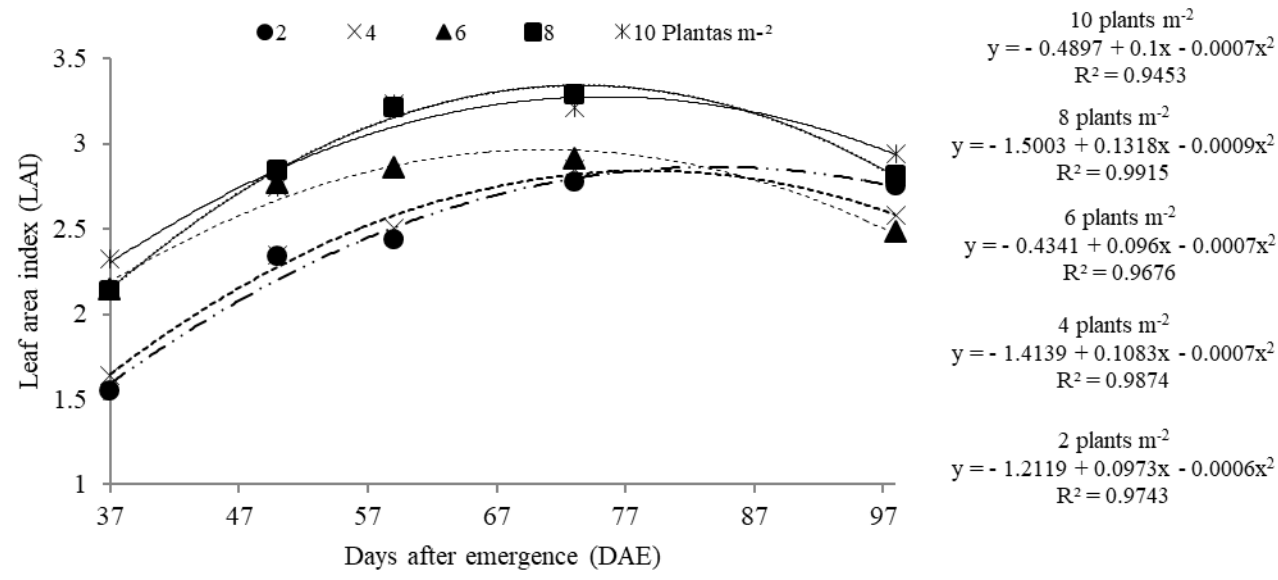

Fig 3. Effect of planting densitiy on leaf area index in maize triple hybrid plants BRS-3046 grown under rainfed conditions at row spacing of $0.5 \mathrm{~m}$ in Teresina, Pl, Brazil. 


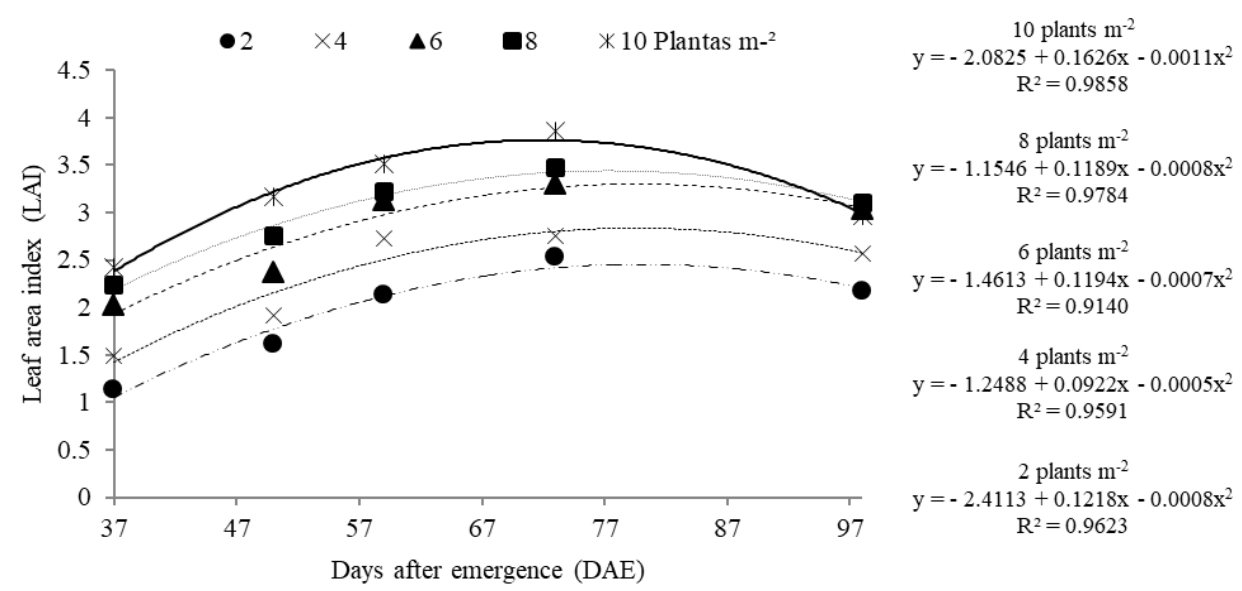

Fig 4. Effect of planting density on leaf area index in maize triple hybrid BRS-3046 grown under rainfed conditions at $1.0 \mathrm{~m}$ row spacing in Teresina, $\mathrm{Pl}$, Brazil.

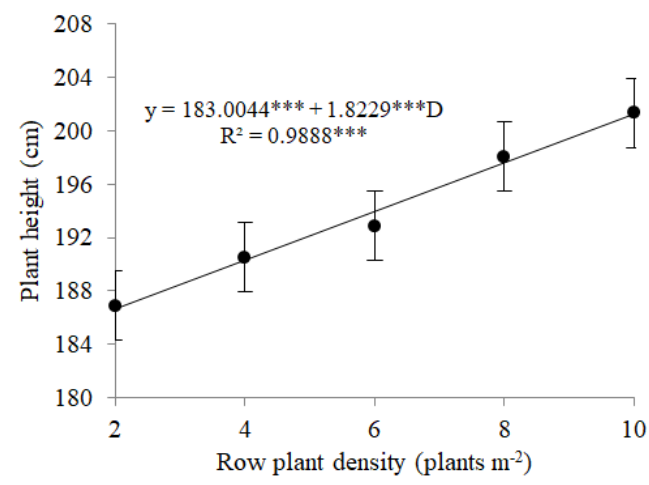

B

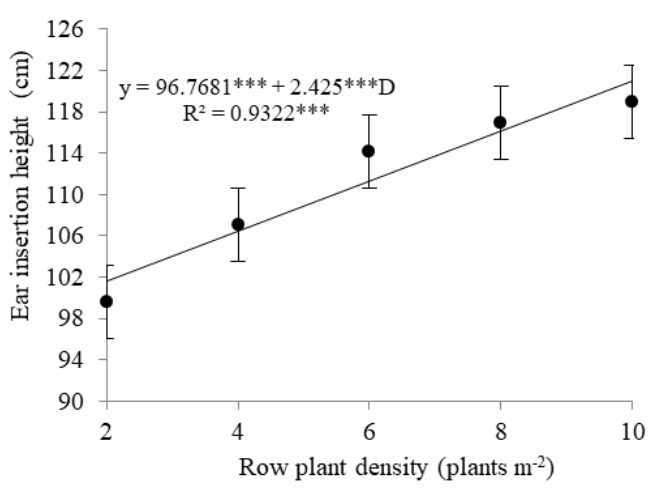

Fig 5. Morphological characteristics in maize triple hybrid BRS 3046 plants submitted to different row spacings and plant densities under rainfed conditions in Teresina, PI, Brazil. Significance according to F test: ${ }^{* * * \prime} 0.001 \%^{\prime * * \prime} 0.01 \%^{\prime * \prime} 0.05 \%^{\prime \prime} 0.1 \%$ of probability.

A

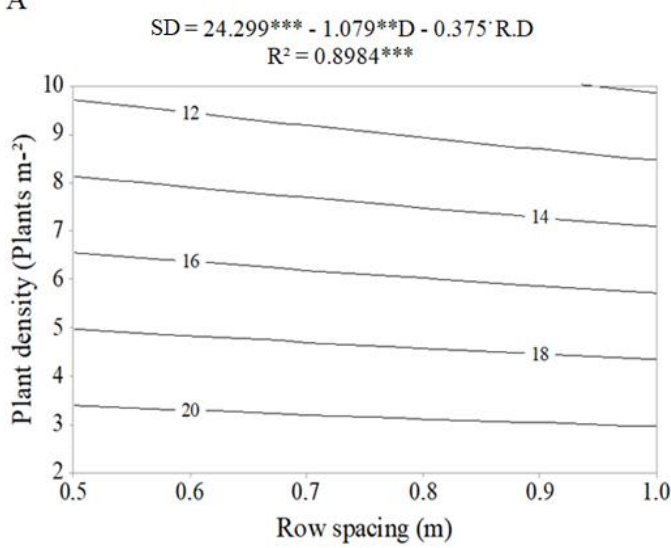

B

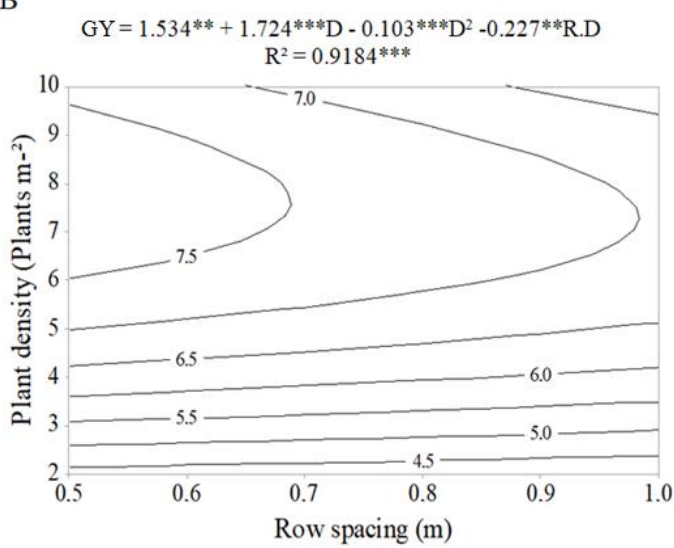

Fig 6. Response surface curves for stem diameter (A) and grain yield (B) in maize triple hybrid BRS-3046 plants submitted to different row spacings and plant densities under rainfed conditions in Teresina, PI, Brazil. Significance according to $\mathrm{F}$ test: '***' $0.001 \%^{* * \prime} 0.01 \%^{\prime * \prime} 0.05 \%$ ' $0.1 \%$ of probability. 


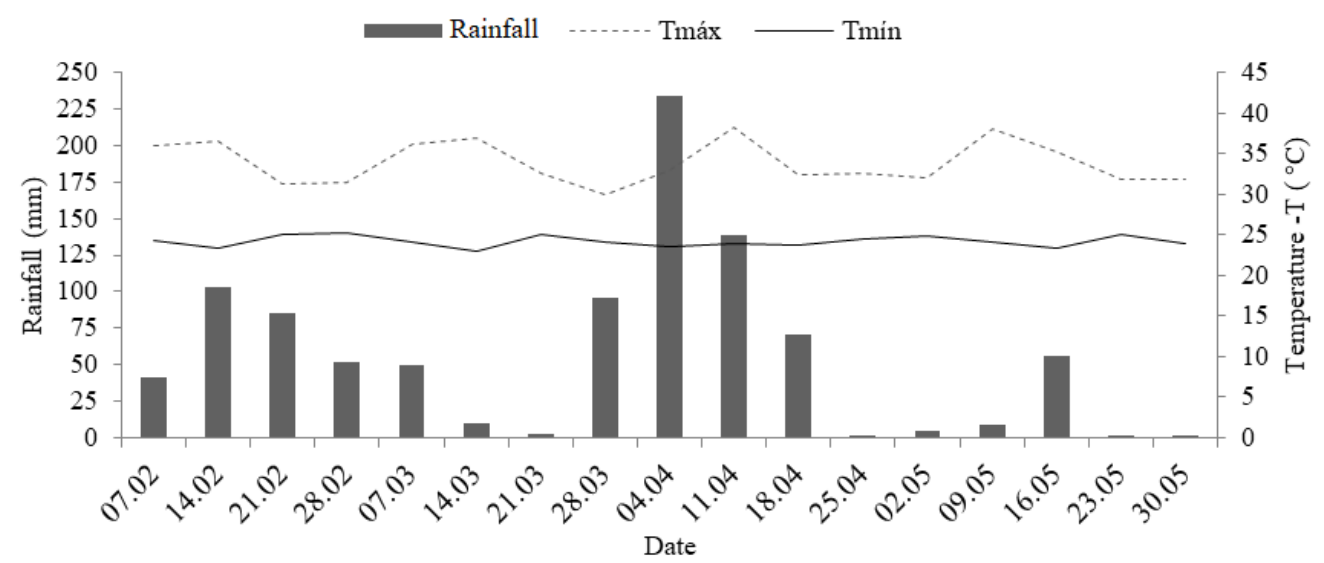

Fig 7. Weekly records of rainfall, maximum and minimum air temperature in the experimental area from germination $(02 / 07 / 2017)$ at the end of the experiment $(05 / 30 / 2017)$.

the photosynthetic process and, consequently, demand less $\mathrm{CO}_{2}$ (Poole et al., 1996; Onwueme et al., 2000).

Plant height and ear insertion height are two important agronomic characteristics in maize plants, which are related to population density (Li et al., 2016). Increasing plant density can improve maize yield. However, in higher densities, plants can compete for water and mineral nutrients in the roots and light in the shoot, resulting in longer and thinner stems (Shi et al., 2016; Fromme et al., 2019), as occurred in this study.

The increase in row spacing allowed obtaining maize plants with thicker stem. However, it was observed that higher plant densities resulted in thinner stems (Fig 6A). In fact, high plant densities may favor apical dominance, selfshading and less light interception, and therefore less distribution of photoassimilates, hampering the development of other organs such as stem and grain filling (Cabrera-Bosquet et al., 2017; Azam et al., 2017).

The results obtained for grain yield by the maize hybrid BRS3046 plants indicated that the reduction of row spacing is more advantageous when associated with higher planting densities up to 8 plants $\mathrm{m}^{-2}$ (Fig 6B). Beyond this, there is a reduction in grain yield. This is why increasing plant density beyond the optimum impairs the formation of ears since it decreases the number of grains and the biomass accumulation (Santos et al., 2018).

\section{Materials and methods}

\section{Characterization of the experimental area}

The experiment was carried out at the Embrapa Mid-North experimental station, in Teresina, $\mathrm{PI}, \mathrm{Brazil}\left(5^{\circ} 05^{\prime} \mathrm{S}, 42^{\circ} 29^{\prime} \mathrm{W}\right.$ and $72 \mathrm{~m}$ of altitude) from February to May 2017. According to the Thornthwaite and Mather's (1955) climate classification, the climate of the region is C1sA'a', characterized as sub-humid dry, megatermic, with moderate water surplus during summer. It presents a mean annual temperature of $28.2^{\circ} \mathrm{C}$, mean maximum temperature of $33.8^{\circ} \mathrm{C}$ and mean minimum temperature of $22.6 \circ \mathrm{C}$, mean relative air humidity of $69.8 \%$ and mean rainfall of 1330.8 $\mathrm{mm}$ per year (Bastos and Andrade Júnior, 2015). The daily climatic data throughout the experiment were obtained from a weather station of the National Institute of Meteorology - INMET (Fig 7).
The soil of the experimental area was classified as Eutrophic Fluvic Neosol according to the Brazilian Soil Classification System (Melo et al., 2014). Fertilization was performed based on the soil physico-chemical analysis (Table 3 ) and on the recommendation for maize in the region (Cardoso et al., 2011). Thus, $75 \mathrm{~kg}$ of $\mathrm{N} \mathrm{ha}^{-1}, 70 \mathrm{~kg}$ of $\mathrm{P}_{2} \mathrm{O}_{5} \mathrm{ha}^{-1}$ and $60 \mathrm{~kg}$ of $\mathrm{K}_{2} \mathrm{O} \mathrm{ha}^{-1}$ were applied in the soil before sowing. Supplemental nitrogen fertilization was performed when the plants had the sixth mature leaf, by applying $45 \mathrm{~kg}$ of $\mathrm{N}$ $\mathrm{ha}^{-1}$ in the soil. Ammonium sulfate, triple superphosphate and potassium chloride were used as sources of $\mathrm{N}, \mathrm{P}_{2} \mathrm{O}_{5}$ and $\mathrm{K}_{2} \mathrm{O}$, respectively.

\section{Plant material and growth conditions}

Seeds of commercial maize triple hybrid BRS-3046 from Embrapa were used. Sowing was performed manually on February 2, 2017, using two seeds per well. The experiment was conducted under rainfed conditions. In accordance with the conventional planting system used in the region, plowing and harrowing were previously performed.

Before sowing, preventive weed control was performed by applying a mixture of pre-emergent herbicides to the soil, using a mixture of atrazine and s-metolachlor $(1,480+1,160$ $\mathrm{g} \mathrm{ha}^{-1}$ of a.i). When the maize plants were at the V3 growth stage, weed control was reinforced by the application of the herbicide tembotrione (100.8 g.ha ${ }^{-1}$ of active ingredient). The control of Spodoptera frugiperda was conducted through the application of the insecticide lufenuron (15 g.ha${ }^{1}$ of a.i) upon noticing the first visual symptoms of attack.

\section{Measured variables}

At 45 days after emergence (DAE), measurements of foliar gas exchange and leaf area index (LAI) were conducted. At $49 \mathrm{DAE}$, plant height $(\mathrm{PH})$, ear insertion height $(\mathrm{EIH})$ and stem diameter (SD) were determined. Ears were harvested upon reaching physiological maturity.

For gas exchange measurements, a portable gas analyzer was used in the infrared region of the electromagnetic spectrum, LI-COR Mod. 6400XT (LI-COR, Lincoln, NE, USA), equipped with a measuring chamber with artificial illumination LI-COR Mod. 6400-02B. The equipment was configured to maintain the relative humidity within the measuring chamber between 50 and $60 \%$, with the block temperature set to $35^{\circ} \mathrm{C}$. The light intensity inside the measuring chamber was set to $2000 \mu \mathrm{mol} \mathrm{m}^{-2} \mathrm{~s}^{-1}$, the air flow 
rate to $400 \mu \mathrm{mol} \mathrm{s} \mathrm{s}^{-1}$ and the $\mathrm{CO}_{2}$ concentration at $400 \mathrm{ppm}$ in the reference cell, using a $\mathrm{CO}_{2}$ mixer mod. 6400-01 (12 g $\mathrm{CO}_{2}$ cylinder). Measurements were performed between 07:00-09:00h in one plant per plot, on the middle third of the ear leaf. The extracted data, provided by OPEN version 6.3 software, were: $A=$ net assimilation rate of $\mathrm{CO}_{2}(\mu \mathrm{mol}$ $\left.\mathrm{CO}_{2} \mathrm{~m}^{-2} \mathrm{~s}^{-1}\right), g s=$ stomatal conductance to water vapor $\left(\mathrm{mmol} \mathrm{H} 2 \mathrm{O} \mathrm{m}^{-2} \mathrm{~s}^{-1}\right), E=$ transpiration rate $\left(\mathrm{mmol} \mathrm{H}_{2} \mathrm{O} \mathrm{m}^{-2} \mathrm{~s}^{-}\right.$ $\left.{ }^{1}\right), \mathrm{Ci}=$ intercelular $\mathrm{CO}_{2}$ concentration $\left(\mu \mathrm{mol} \mathrm{CO} \mathrm{mol} \mathrm{air}^{-1}\right)$, EiUA $=$ instantaneous efficiency in water use $\left(\mu \mathrm{mol} \mathrm{CO}_{2}\right.$ mmol $\mathrm{H}_{2} \mathrm{O}^{-1}$ ) and $\mathrm{EiC}=$ instantaneous carboxylation efficiency $\left(\mathrm{mol} \mathrm{m}^{-2} \mathrm{~s}^{-1}\right)$.

Leaf area index (LAI) was determined using a LI-COR brand analyzer LAI-2000 (LI-COR, Lincoln, NE, USA). The LAI-2000 uses a light sensor that measures the diffuse radiation simultaneously in five angular bands (0-13, 160-28, 320$43^{\circ}, 470-58$ ond $\left.61^{\circ}-74 \%\right)$. For each plot, one measure of the diffuse radiation incident on the canopy and three under the canopy were carried out.

Plant height $(\mathrm{PH})$ and ear insertion height (EIH) were measured using a measuring tape. $\mathrm{PH}$ was considered as the distance from the soil surface to the insertion of the flag leaf, while EIH as the distance from the soil surface to the insertion point of the upper ear. The stem diameter (SD) was measured using a digital caliper, in the region just below the insertion of the first ear. For these variables, the value per plot corresponded to the average of three plants situated in the central area of the plot.

Ear harvesting was carried out on June 5, 2018. Grain yield was determined by extrapolating the yield obtained in the plots to hectares. Grain moisture was corrected to $13 \%$.

\section{Experimental design and statistical analysis}

Plants were grown at two row spacings $(0.5$ and $1.0 \mathrm{~m})$ and five plant densities $\left(2,4,6,8\right.$, and 10 plants $\left.\mathrm{m}^{-2}\right)$. A randomized complete block design was used. The treatments were arranged in $2 \times 5$ factorial sheme, with four replicates. The experimental plot consisted of four rows with five meters of length. Only the two central rows were considered for data collection.

The data were submitted to the Shapiro-Wilk and Cochran T tests for normality of errors and homogeneity of variance, respectively. Once the basic requirements were met, the data were submitted to variance analysis. The effects of row spacing and planting density were analyzed by polynomial regression according to Zimmermann (2014). The reduced model was adopted consisting of nine parameters containing the isolated linear and quadratic effects and by the first and second degree double interactions, as follows:

$$
\begin{gathered}
Y=b 0+b 1 A+b 2 A^{2}+b 3 B+b 4 B^{2}+b 5 A B+b 6 A B^{2} \\
+b 7 A^{2} B+b 8 A^{2} B^{2}
\end{gathered}
$$

Where:

Y: dependent variable;

b0: constant of regression;

b1,...,b8: regression coefficients

$A$ and $B$ : independent variables, constituted by line spacing and plant density, respectively.

As a function of the $t$ test, the best model was selected, accepting significance level up to the limit of $15 \%$ of probability (Conagin, Jorge, 1982). All statistical analyses were performed using $R$ software version 3.4.1 ( $R$ Development Team, 2006).

\section{Conclusions}

The row spacing and plant density affected, individually or in interaction, the morphophysiological characteristics and gas exchange rates in the of maize triple hybrid BRS-3016 plants. The plant spatial arrangement that maximized grain yield in the maize triple hybrid BRS-3016 plants was a combination of a row spacing at $0.5 \mathrm{~m}$ and 8 plants $\mathrm{m}^{-2}$.

\section{Acknowledgmehts}

To Embrapa for funding. M. W. L. Carvalho thanks $\mathrm{MCTI} / \mathrm{CAPES}$ for the scholarship grant.

\section{References}

Abuzar RM, Sadozai UG, Baloch MS, Baloch AA, Shah IH, Javaid T, Nazim H (2011) Effect of plant population densities on yield of corn. J Anim Plant Sci. 21(4): 692-695.

Antoniettaa M, Fanelloa DD, Acciaresib HA, Guiamet JJ (2014) Senescence and yield responses to plant density in stay green and earlie-senescing corn hybrids from Argentina. Field Crops Res. 155: 111-119.

Argenta G, Silva PRF, Sangoi L (2001) Arranjo de plantas em milho: análise do estado-da-arte. Cienc Rural. 31(6): 10751084.

Azam M, Akbar N, Akhter MJ, Sajjad AA (2017) Production potential of various corn (Zea mays L.) hybrids under different intra-row plant spacing. Pak J Agri Sci. 54(1): 117121.

Barradas TFS, Santos ACP, Moro AL, Araujo FF (2018). Bacillus subtilis [Ehrenberg. (1835) Cohn 1872] improves water use efficiency in corn under drought conditions and two light intensities. Appl Ecol Env Res. 16(4): 3885-3895.

Bastos EA, Andrade Júnior AS (2015) Boletim agrometeorológico do ano de 2014 para o município de Teresina, PI. Documentos/Embrapa Meio-Norte. 185: 38.

Buso WH, Silva LB, Rios ADF, Firmino RS (2016) Corn agronomic characteristics according to crop year, spacing and plant population densities. Comun Sci. 7(2): 197-203.

Cabrera-Bosquet L, Grieder C, Alvarez Prado S, Sánchez C, Araus JL (2017) Kernel $\delta 18$ o reflects changes in apical dominance and plant transpiration in tropical corn. J Agron Crop Sci. 203(4): 277-285.

Cardoso MJ, Ribeiro VQ, Melo FB (2011) Performance de Cultivares de Milho-Verde no Município de Teresina, Piauí. Documentos/Embrapa Meio-Norte. 227: 4.

Companhia Nacional de Abastecimento CONAB. Acompanhamento da safra brasileira de grãos safra 2017/2018. 5(10): 1-178. Accessed on: 03/fev/2019, Avaliable at: http//www.conab.gov.br.

Conagin A, Jorge JPN (1982) Delineamento (1/5) $(5 \times 5 \times 5)$ em blocos. Bragantia. 14(16): 115-168.

Fromme DD, Spivey TA, Grichar WJ (2019) Agronomic response of corn (zea mays L.) hybrids to plant populations. Int J Agro. 2019:1-8.

Gondal MR, Hussain A, Yasin S, Musa M, Rehman HS (2017) Effect of seed rate and row spacing ongrain yield of sorghum. SAARC J Agri. 15(2): 81-91.

Gonzalez VH, Tollenaar M, Bowman A, Good B, Lee EA (2018) Corn Yield Potential and Density Tolerance. Crop Sci. 58: 114.

Gou L, Xue J, Qi B, Ma B, Zhang W (2017). Morphological Variation of Corn Cultivars in Response to Elevated Plant Densities. Agron J. 109(4), 1443-1453. 
Kappes C, Andrade JAC, Arf O, Oliveira AC, Arf MV, Ferreira JP (2011) Arranjo de plantas para diferentes híbridos de milho. Pesq Agropec Trop. 41(3): 348-359.

Li X, Zhou Z, Ding J, Wu Y, Zhou B, Wang R, Ma J, Wang S, Zhang X, Xia Z, Chen J, Wu J (2016) Combined linkages and association mapping reveal QTL and candidate genes for plante ar height in corn. Front Plant Sci. 7: 1-11.

Lima CF, Arnhold E, Araujo BL, Oliveira GHF, Oliveira Junior ED (2012) Avaliação de híbridos de milho sob três densidades populacionais em fronteira agrícola no Maranhão. Comun Sci. 3(1): 30-34

Marchão RL, Brasil EM, Ximenes PA (2006) Interceptação da radiação fotossinteticamente ativa e rendimento de grãos de milho adensado. Rev Bras Milho Sorgo. 5(2): 170-181.

Melo FB, Andrade Junior AS, Pessôa BLO (2014) Levantamento, zoneamento e mapeamento pedológico detalhado da área experimental da Embrapa Meio-Norte em Teresina, PI. Documentos/Embrapa Meio-Norte. 231: 47.

Onwueme IC, Johnston M (2000) Influence of shade on stomatal density, leaf size and other leaf characteristics in the major tropical root crops, tannia, sweet potato, yam, cassava and taro. Exp Agric. 36(4), 509-516.

Pimentel C (1998) Relações fonte/dreno. In: metabolismo de carbono na agricultura tropical. 9rd edn. Seropédica, Rio de Janeiro. 2.

Poole I, Weyers JDB, Lawson T, Raven JA (1996) Variations in stomatal density and index: implications for palaeoclimatic reconstructions. Plant Cell Environ. 19(6), 705-712.

R Development Core Team (2006) R: A Language and Environment for Statistical Computing. Vienna: R Foundation for Statistical Computing. Accessed on: 15/dec/2018, Avaliable at: http://www.R-project.org.

Ren B, Li L, Dong S, Liu P, Zhao B, Zhang J (2017). Photosynthetic Characteristics of Summer Corn Hybrids with Different Plant Heights. Agron J. 109:1454-1462.
Ricaurte J, Michelangeli JAC, Sinclair TR, Sinclair TR, Rao IM, Stephen B, (2016) Sowing density effect on common bean leaf area development. Crop Sci. 56: 1-9.

Santos ALF, Mechi IA, Ribeiro LM, Ceccon G (2018) Eficiência fotossintética e produtiva de milho safrinha em função de épocas de semeadura e populações de plantas. Rev Agric Neotrop. 5(4): 52-60.

Shi DY, Lil YH, Zhang JW, Liul P, Zhao B, Dong ST (2016) Effects of plant density and nitrogen rate on lodging-related stalk traits of summer corn. Plant Soil Environ. 62(7): 299-306.

Souza RS, Vidigal Filho OS, Scapim CA, Marques OJ, Queiroz DC (2013) Elementos de produção de milho doce em diferentes densidades populacionais. Comun Sci. 4(3): 285-292.

Thornthwaite CW and Mather JR (1955) The Water Balance. In: Climatology. 8rd edn. Centerton, New Jersey.1.

Valadabadi SA and Farahani HA (2010) Effects ofplanting density and pattern on physiologicalgrowth indices in corn (Zea mays L.) undernitrogenous fertilizer application. J Agric Ext and Rural Dev. 2(3): 40-47.

Wang J, Huang $H$, Jia S, Zhong $X$, Fenghai L, Zhang KK, Shi Z (2017) Photosynthesis and chlorophyll fluorescence reaction to different shade stresses of weak light sensitive corn. Pak J Bot. 49(5): 1681-1688.

Xue J, Zhao Y, Gou L, Shi Z, Yao M, Zhang W (2016) How High Plant Density of Corn Affects Basal Internode Development and Strength Formation. Crop Sci. 56(6): 3295-3306.

Zhao KF (1981). Effect of the leaves of different positions in corn on the corn yield and the photosynthetic properties of those leaves after the growing out of the female flowers. Acta Agron Sin. 4: 259-266.

Zimmermann FJP (2014) Experimentos fatoriais fracionados: análise de variância e uso para estudo de superfícies de resposta. In: Estatística aplicada à pesquisa agrícola. 2 rd edn. Santo Antônio, Goiás. 14. 